\title{
WITHOUT WALT WHITMAN IN CAMDEN
}

\author{
JOANN P. KRIEG
}

Admittedly, the above title is designed to provoke a mental association for it parodies that Boswellian marvel, With Walt Whitman in Camden, the nine-volume diary of Horace Traubel's visits to the Mickle Street house from March 1888 to the day of Whitman's death four years later. In the absence of a full biography, the closest thing we have to a record of Traubel's life without Whitman, especially in the years immediately after the poet's death, are Traubel's letters to J. W. Wallace in Bolton, England. Difficult to gain access to-because they are part of a collection housed in the Bolton library-and time-consuming to decipher, the letters are rewarding, nonetheless, for a number of reasons. For one thing, they provide a fuller picture of Traubel than do the diaries and allow us to hear him in exchanges with others, rather than only with Whitman. Then too, the letters reveal a great deal about the adjustments required of Whitman's closest admirers to the fact of his death, and the enormous sense of responsibility that settled on his literary executors, Richard M. Bucke, Thomas B. Harned, and Horace Traubel. There are touches of humor in some of the letters, indications of disagreements among the first members of the international community of Whitmanites, and discussions of the Whitman "cause" in relation to socialism. Of special interest to contemporary scholars is the revelation that some of the very things that most preoccupy us about Whitman, especially the question of his sexuality, also preoccupied that band of early followers to whom Traubel frequently refers as the poet's "lovers."1

Lovers they certainly were, of the man, his genius, and his work, but they were disciples as well, as we know from the hagiographies that appeared soon after his death and the energy brought to the early dissemination of Whitman's "gospel." The desire to spread "the creative Word of Democracy" embodied, as they believed, in the person and work of Walt Whitman, led his American followers to reach out to those in other countries who shared their enthusiasm, and in Bolton a beachhead had already been established. In fact, the flow of correspondence between Traubel and Wallace stemmed from the time of Wallace's visit to Whitman in the autumn of 1891 . Wallace was the founder of a bookish group of young Bolton men who met weekly at his home on Eagle Street to read and discuss many matters, but especially the poetry of 
Walt Whitman. ${ }^{2}$ After receiving a warm response to their first hesitant and very respectful greeting to the poet, the "Eagle St. College" (as it was fondly dubbed) and its principal object of interest maintained a steady stream of mail across the ocean. Then in 1890 the collegians sent one of their number, Wallace's close friend Dr. John Johnston, to meet Whitman in person. He remained in the States most of the summer, visiting not only at Camden, but also the poet's birthplace on Long Island, the Rome brothers' Brooklyn printing establishment, and the English artist Herbert Gilchrist who had settled in Centerport, Long Island.

The following summer R. M. Bucke visited Johnston in Bolton and urged Wallace to accompany him to Camden. While Wallace deliberated this, Bucke left for a visit with Alfred Lord Tennyson and returned to Bolton in the company of poet and socialist reformer, Edward Carpenter. Wallace decided to make the trip to the States, and on September 8, 1891, was greeted on his arrival in Philadelphia by Horace Traubel and Warren Fritzinger, Whitman's nurse. ${ }^{3} \mathrm{He}$ left Camden for England in November and never returned, but so firmly established was the relationship between himself and Traubel, that they continued to correspond, though with diminished frequency, until 1919 when Traubel died. The diminution of correspondence was not gradual, however, but suffered a severe falling off in the year 1896 when Traubel wrote only 43 letters, after having written 313 in 1895, 240 in 1894, and 309 in 1893. ${ }^{4}$ Part of this account of their correspondence is the story of its sharp decline and the reasons for it, as drawn from their letters and the letters of others.

Traubel's early affection for his English friend is conveyed by such declarations as (with a fervency evident even in the pressure of pen on paper), "My heart goes over the sea to you." For his part, Wallace displayed an even greater degree of devotion, mainly because his was a more poetic nature and his love for Traubel, and others, seems always to have been fully expressed in words. Wallace's view of Traubel was that he was the "John of our band-the disciple whom Walt loved." Often his letters seem effusive in their praise of Traubel-for his filial devotion to Whitman in the final illness, his industry in publication, and in the many Whitman-related projects undertaken almost immediately after the poet's death. In fact, Traubel was a wonder in all of these, and more, but there appears to have been another reason for the oft-repeated words of praise. Traubel was easily made jealous by Wallace's expressions of love and admiration for others in the international Whitman circle, such as Edward Carpenter, so that Wallace often felt the need to reassure his friend of his affection. Wallace, however, suffered with a severe eye affliction which caused him great difficulty in reading and writing, thus he was not able to keep pace with Traubel's 
steady, almost daily, flow of letters. And because there were many others who shared his love of Whitman, Wallace was obliged to answer their letters as well, leaving him frequently to beg Traubel's indulgence. ${ }^{5}$

What follows is a chronology of issues and events mentioned in the voluminous correspondence from Traubel to Wallace between 1892 and 1895, with references to Wallace's letters added for clarification. Where possible, further reference is made to other sources and other correspondence to illuminate their discussions.

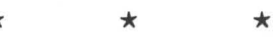

Before he could even begin to act in his capacity as literary executor, Traubel had to face his own grief and deep sense of loss. "Dear, dear Walt!," he exclaimed less than three months after the death, gratefully, though sorrowfully, extolling to Wallace the effect of the poet's memory of his life, adding, "And he speaks yet in every hour I live." But there were tasks to be done, such as the clearing away of the clutter with which Walt had surrounded himself in his bedroom. With the Rev. J. H. Clifford, who had married Traubel and Anne Montgomerie in the spring of 1891 in a ceremony that took place at Walt's bedside, he climbed once more the old staircase. "[O]n seeing Walt's old papers there, basketed, boxed, waiting the arranging hand, the tears came to [Clifford's] eyes. 'I can hardly believe him dead,' he averred; 'it seems impossible.' 'Nor is he,' I protested, 'how could death have come?'” Still, the summer was upon them; Traubel and his wife had become parents in April with the birth of their daughter, Gertrude, and, despite his loss, Traubel was able to end his letter with, ". . . the fact is, I am happy" (June 3, 1892).

Changing seasons and the memories they evoked brought other sentiments, however, and in October Traubel was overwhelmed by thoughts of the previous year's autumn when Wallace and Walt were with him: "Clouds have come and gone since then. Some hearts then beating now are dust. But heart's love? It is ever the same; ever the child I touch his hand. I see the light rise to his eyes again and the flush on the cheeks. And resonantly I hear again the word of greeting or departure. All is precious for love. . . . Does not your heart hum fast its songs, now and then? Not to gravelands but to life, to him, our supreme comrade, in whom flowed the matchless virtues and affections. I am sad tonight. I long for him. Dear Wallace, my love, my love." These effusions may have embarrassed the writer, who adds a postscript, "After the manful power and love of all your friends in Bolton do not my utterances seem very cheap and superfluous?" But the next day the mood was still upon him as he longed to return to the previous year and to the dream he shared with Whitman of love, "Love of man and woman and child. Comradely duties. The fraternal hand!" (October 13, 1892). 
At the end of the month Traubel went to clear out more of the things in the bedroom at 328 (changed not long after to 330) Mickle Street. He shipped to Bucke, in Canada, the water bed-a mattress filled with water commonly used by invalids - on which Whitman lay for the two days before his death. While in the room attending to these things, he tells Wallace, "a thousand phantoms" gathered and "could have made me weep." "I feel the sad past, the glorious past, the holy and exhilarating past, and yet can weep and call for a touch of his dear hand again. Absalom! Absalom! Let the daybreak come. I know he will be in the dawn! On some other shore he perhaps even now chants new songs and carols with nature for her tenderest ends and mysteries."6 Traubel concludes his letter by speaking of the joys of parenthood he and Anne were experiencing, so that it ends, "We seem to have ushered from the clouds" (October 31, 1892).

Meanwhile, despite counsel from Wallace and Carpenter in England to rest for a time and postpone hasty publication, preparation had begun of In Re Walt Whitman, a joint publication of the literary executors which Traubel worked on ardently and cheerfully, drawing on his faith in Walt's abiding presence as on "a past joy." There were problems, however, such as in controlling the information contained in the mass of letters written to and by Whitman. Trouble began with what Traubel viewed as William Sloane Kennedy's indiscretion in releasing for publication some comments on Alfred Lord Tennyson contained in a letter addressed to Whitman by Bucke. ${ }^{7}$ This was, in fact, the second time Kennedy had offended in this way. In October of 1891 Whitman had thundered at a similar breach of confidentiality in the Boston Transcript, declaring, "Wrong! Yes, wrong! Kennedy is guilty of trespass!" According to Traubel, Walt had allowed Kennedy to read the letter but with the stipulation that the contents not be publicly revealed. Despite his agreement to this stipulation, and barely six months after Whitman's death, Traubel believed that Kennedy had released some of the information to the Philadelphia Record. On October 9, 1892, he wrote Wallace that on that day there appeared in the paper a quote, without attribution, from Bucke's letter. Traubel's conclusion was that Kennedy had acted "rather shabbily in this matter." While the "matter" is of small consequence, it indicates something of the divisions that existed early on within the circle of disciples and points the way toward much larger areas of disagreement that arose later. ${ }^{10}$

As the fateful year 1892 drew to an end, there was news to communicate to Bolton of yet another death in the Whitman family:

You will be startled to learn that Eddie Whitman is dead and was today buried in the tomb at Harleigh. I could not get out to the grounds, as I did not learn of the death till last night, and I had another engagement in Phila. this afternoon. The Whitman family seems to be rapidly breaking up. Good and bad, they go the same road. Walt, Mrs. 
Whitman [George Whitman's wife], Heyde [Walt's brother-in-law, Charles Heyde], Eddie. Poor Eddie! It was his sore part to bear himself through life afflicted. He knew nothing of it, but others knew it for him. Now they sleep side by side-the greatest and the least - the light of our world, the prophet of an epoch-the universal seer-and the poor half-halting soul, not given the first glimpses of day. (December 3, 1892)

Eddie's unexpected death opened the way to possible acquisition of the Mickle Street house, which Traubel and Harned hoped to preserve as a shrine. The house had been left to George Whitman, who was to sell it and use the proceeds for Eddie's care at the mental hospital where he had been confined for years. Traubel believed George could be made to see the wisdom of turning the house over for preservation, and set about convincing him. His efforts proved unsuccessful, however, even when he and Harned combined a visit to George to ask about the house with an interview about Walt's early life, which was to be included in the book they were planning. George was unmoved by this promise of fame and remained "a stolid uncommunicative man," almost a "blank," and of no use at all in providing information about those parts of Walt's life that remained a mystery. "That a man like Walt, moving among them [members of the Whitman family] should have left so slight an impression!" he moaned to Wallace (February 7, 1893). ${ }^{11}$

Traubel also tried to establish a fund for purchase of the house, if necessary, or for needed repairs should George be made to see the light and donate it. Responses to this effort were generally good in the United States, but refusals from Dr. S. Weir Mitchell and George W. Childs annoyed Traubel enough to cause him to report the fact. ${ }^{12}$ There were complaints too about Wallace's countrymen- "Not a cent from England"- though one doubts that he means to include the Bolton admirers, but rather the more literary English figures, such as Edward Carpenter, who, he says, "wishes to give a little." John Addington Symonds, he noted, had sent five pounds (January 27, 1893). ${ }^{13}$

While In $R e$ was in proofs Traubel worked on a double issue of the Conservator and on a history of Camden. He was also gathering together for publication Whitman's letters to his mother written from Washington during his illness in 1873, and still seeking acquisition of the Mickle Street house. In addition he wrote numerous articles on Whitman and maintained steady contact with Whitmanites in the States and abroad. There was competition among them for Whitman materials, and more than a little anxiety on Traubel's part about the many works-in-progress by others and how they would portray the Master. Traubel seems to have wanted to control the Whitman image, perhaps seeing the role of literary executor as conferring on him a certain right to do so. Within the year after Walt's death, however, Kennedy, Burroughs, Brinton, and Symonds were all at work on Whitman books. 
New Year's Eve, 1892, brought together "60 to 70 people at Harned's," though Traubel, writing of the event to Wallace in advance, doubted that many would be "true Whitmanites." Even so, he concluded that it is "good to assemble in Walt's name. It raises the standard-swears to it a lordly fealty. I bless that name, it stands for so much that makes life holy and so much that rounds character and opens the ways of the future" (December 29,1892). But with the new year Traubel found himself involved in further unpleasantness arising from the use of letters to or from the poet. Early in 1893 he reported to Wallace that Edward Carpenter and John Addington Symonds had written to him expressing concern over Traubel's publishing plans. Symonds feared that a "private" letter would be made public and wrote in "an angry mood." Carpenter, too, "seems to exercise himself a great deal in the fear that we are likely to dance a fool's dance over the memory of Walt," Traubel wrote (January 8, 1893).

Even before this letter was dispatched to Wallace, Symonds had responded to what must have been a troubled letter from Traubel, for on December 12, 1892, he wrote:

I am sorry to have vexed you with the letter I wrote last. . . . I know that I have written out of my heart \& life's experience to W.W. I also know that on the other side of the Atlantic there is not the same feeling about personal communications as are here in England. To put it frankly, I used then to feel that W.W. exceeded the bounds of modesty \& good breeding, \& did injustice to his own dignity \& genius, by hawking around extracts from utterances of private persons, instead of leaving his own great work in the way that Dante \& Milton did-to shine like a star. So, I think I was justified in having a suspicion that words of mine written for him alone might be used to advertise him. W.W. wants no advertisement except by [his] own very peculiar \& unique work.

The letter to which Symonds referred was probably not the one he wrote to Whitman seeking a final word on the meaning of the "Calamus" poems, since there is nothing in it of Symonds's past life that would account for a threat he made to Traubel, that he had "told Whitman things about my own past life ... the diffusion of which would not only cause me great pain, but would also provoke me to a violent attack on Whitman's literary executors." ${ }^{14}$ It may have been that Symonds had his own plans for the letter, perhaps intending to publish it in the study of Whitman he was preparing. Or it may have been that he did not wish to have made public certain private sentiments he had expressed to Whitman, to the effect that he himself did not believe the possible physical intimacies that might arise from the "enthusiasm of "Calamus" would be "absolutely prejudicial to Social interests." 15

A decade later Edward Carpenter also became insistent on the same point, with reference to the publication of the diary Traubel had kept: "Do not however insert any of my letters to Walt without my sanction." Then, on the question of the letters between Symonds and Whitman, he adds: 
Tho' I have not seen Symonds' letter of query, I guess it was a little ill-judged, \& that it threw upon W. the incubus so to speak of defending himself from accusations, \& therefore caused W. to write less freely than he else might have done. In these ways the publication of the letters will possibly convey false impressions. On the other hand there is further material in W's letter, about his children, which is valuable- \& which I suppose is correct-tho' strange \& others of course deny its correctness. There is no doubt that Walt's memory in latest years was shaky at times, about circumstances of his work \& life (as for instance in "A Backward Glance"-about the genesis of L. of G. from the war) - tho' in the main correct enough. Shall you put in any sort of note, just indicating this in a general way-without applying it to particular statements? (August 7, 1903)

\section{Whitman's denial of any such intent for "Calamus" as that which} Symonds detected had done nothing to allay Symonds's suspicions. In mid-December of 1892 he wrote to J. W. Wallace still claiming to be "perplexed" about "Calamus." Whitman's disclaimer aside, he told him, "there are certainly a large number of men born with 'homosexual' tendencies, who could not fail, while reading 'Calamus,' to think their own emotions justified by Whitman." ${ }^{16}$ On January 3, 1893, Wallace wrote to Traubel:

I have written quite a long letter to Symonds today-of 16 closely written pages - in reply to his last letter. It seems curious to me that it should fall to my lot to explain to him what the "drift" of Calamus is and to show how ungrounded are the fears which he entertains of one direction of its possible influence. Is it not a striking illustration of the sophistication and stinting effect of what is called "literary culture" that Symonds should find "no one of his own pursuits or condition" who can sympathise with his appreciation of W. W. and that he should be so much at sea in dealing with the fresh, natural emotions expressed in "Calamus" and well enough known to simple and unlettered people?

\section{Traubel's response to this was:}

Your enclosure with one of the letters of that message for Symonds interested me greatly. And yet I am not sure but that homosexual stuff he talks of argues bad for his comprehension not only of L. of G. but of the time in which we live. It is not anywhere near any truth that such phenomena plays a considerable part in our history, and it certainly would not appear in L. of G. where there exists the most solid and substantial avowal of sex. Homosexuality is disease-it is muck and rot-it is decay and muck-and Walt uttered the master-cries of health, of salvation, and purity, of growth and beautyalways and everywhere elements vital for up-startings, for blossomings, for repair. It is strange that Symonds should have such theories or such fears. He once referred to them in a letter to me, and Walt afterwards remarked of them: "They are not entirely creditable to Symonds - they do not indicate that he is free." The tremendous urge of L. of G.- the onward-pressingness of its moral tones - the lift and inevitability of its manliness and respect for sex and the natural conditions of life-all prove and make sickly and ridiculous speculations such as these which are spectrally and unpleasantly-uncannily-Symonds'. Of course he will in the end see better-know that Walt was always very glad to let all such doubts take care of themselves. He saw they were bound to be uprooted - to be scorned and despised and be made only a fact in any history of him or his book. We often meet with questions of a nature which would puzzle a saint. No estimate of Walt can ever be thorough until the Adamic attitude is not only understood 
but abandoned. A mere intellectual grasp of the situation will not do. One must emotionally realize it - he must absorb it - he must let it work through him and soak him. Revolutions alone can cleanse the body of the old discredit. "The deliciousness of sex." It fills all the spaces between heaven and hell with glory and joy! L. of G. is dipped in this and is clean. It is a chip out of nature's self!

A number of things in this letter invite comment, the first and most obvious being the use of the word "homosexual," which is surprising mainly for its employment at that time by an American. The word dates to 1869 and the Austrian writer Karoly Maria Benkert, but it did not become part of the general lexicon, especially in America, until early in the twentieth century. John Addington Symonds, the subject of Traubel's letter, was a student of the history of same-sex love, especially love between males, and in his published writings we find him using a number of terms for the phenomenon, though not homosexuality. "Unisexual love" he calls it at one point in his writings, "Uranianism" at another, and finally, in the 1890 book of this title, which he produced in collaboration with Havelock Ellis, "sexual inversion." 17 In his introduction to A Problem in Modern Ethics (1896), he says that European languages have no word for "this persistent feature of human psychology," and that he has settled on "inverted sexuality" because of what he terms its "neutrality." 18 Yet in his letters to Edward Carpenter and others, written as early as 1891 , he uses the word homosexual. Obviously the word was in use among those, such as Symonds and Carpenter, who were most closely involved with the subject, which makes the surprise of finding it in Traubel's letters all the greater, especially when he claims so vehement a disagreement with Symonds's views.

Trained to scholarship, Symonds had traced the history of homosexuality from the Greeks to the modern age, and argued in his writings its enormous influence in the arts and literature. His purpose was twofold, to effect a change in the penal laws of England in favor of private conscience in sexual acts between consenting adults, and to refute the claim of the medical profession that homosexuality was a form of disease. A Problem in Modern Ethics (1891) was addressed, as its title page asserts, "Especially to Medical Psychologists and Jurists," and included as part of its argument a discussion of Whitman's "Calamus" poems along with the poet's denial of their homosexual intent. Clearly Symonds was not yet silenced on the subject of "Calamus," however, since he was still bringing the matter up to Wallace (and to others) as late as 1893. His letter to Traubel, referred to in Traubel's letter quoted above, was written six months after Whitman's denial. Claiming he did not think Whitman quite understood what he was driving at, Symonds dismissed the misunderstanding as of no significance and tried another tack. "I wish you would tell me," he urged Traubel, "what you and your friends feel to be the central point in this most vital doctrine of com- 
radeship. Out here in Europe I see signs of an awakening of enthusiastic relations between men, which tend to assume a passionate character. I am not alarmed by this, but I think it ought to be studied." 19 Though he had stopped trying to force a confession from the elderly poet, it is obvious from this that Symonds was not dissuaded from his suspicion that, "human nature being what it is" (as he had written to Whitman on August 3, 1890), "and some men having a strong natural bias toward persons of their own sex, the enthusiasm of 'Calamus' is calculated to encourage ardent and physical intimacies." 20

Symonds had responded to Whitman's forceful denial in a conciliatory tone, but did not hesitate to offer the poet a "mini-lecture" on amativeness in ancient Greece and its continuance among a "certain percentage" of males in the modern world.$^{21}$ In a letter to Edward Carpenter, Symonds revealed what he thought of Whitman's denunciatory response by pointing out the contradiction between the denial and the subsequent reference to a "spirit impulse," which he says Whitman identified as the "female" in him that he sometimes allowed to rage in Leaves of Grass. The wording of this differs from the draft of Whitman's letter (the original is lost), where the spirit impulse is questioningly referred to as "(?demon)," but since the draft indicates the writer's indecision, there is little reason to believe that Whitman did not revise it to read "female." ${ }^{22}$ Symonds saw this as an admission on Whitman's part, or at least a qualification of the denial, claiming to Carpenter that in light of it, his own "inferences are not so gratuitous morbid and damnable as supposed." ${ }^{23}$ Earlier he had confided to Carpenter that he believed Whitman would not have written the letter when he first published "Calamus," but that now "he was afraid of being used to lend his influence to "Sods" [sodomites]. ${ }^{24}$ As for the postscripted story of the six illegitimate children, Symonds suspected it was Whitman's attempt "to obviate 'damnable inferences' about himself. . . ."25

Traubel's defense of Whitman in the face of Symonds's continuing suspicions is unfailingly staunch, but one cannot fail to notice the wording he employs in doing so. Specifically, when he refers to Symonds's speculations in terms of the spectral, unpleasant, and uncanny, the thought arises that he himself may have been haunted by similar questions about Whitman which he chose not to acknowledge. With this in mind, it is interesting to note that in his discussion of "Calamus" in A Problem of Modern Ethics, Symonds claims that Whitman "has omitted to perceive that there are inevitable points of contact between sexual inversion and his doctrine of comradeship," wording which, in a convoluted way, suggests the poet's willful blindness to a perceivable connection. ${ }^{26}$ Everything in Traubel's letters indicates that he was simply following the Master in this same pattern of imperceptiveness. 
Obviously a difference of opinion existed between the Whitmanites in England and in the United States on this point of Whitman's sexuality, brought about no doubt by the greater awareness of homosexuality that obtained in England. Oscar Wilde's trial for this "crime" was still two years away, but the fact that homosexuality was a criminal offense in England would have made Carpenter, Symonds, and even Wallace, apprehensive about what might be said of Whitmanite "comradeship." Across the ocean, in a society which, in its general repression of sexuality, failed to even acknowledge varied forms of sexual expression, the American Whitmanites either could not comprehend this or chose to remain in blind ignorance of the possibilities for such an interpretation of Whitman's poems. "Poor dear Symonds!," Traubel sighed to Wallace on January 15, 1893, "I think of him often. How could he have left L. of G. with such questions upon his lips?"

In the same month, Traubel wrote to Wallace of some unspecified concerns expressed by the Bolton friends: "But somehow all the fellows mistake Walt in this: they are not as sure of his inevitableness as I am. They have a binding fear that some accident may destroy his life's work and may nullify what he was born to do. But Walt is an outpouring of Nature itself - as little to be disposed of by the petty ways and means that obtain among men as a law of nature. . . . He has given literature new meanings and shown that books may be made to speak from vital inner energy which has never heretofore appeared in printed or written speech" (January 12, 1893). Later that month, Traubel reported to Wallace that he had sent Carpenter's letter, in which he expressed his concern at the planned book, to Bucke, who replied:

If Carpenter, Wallace \& Company are afraid of us that is no reason we should be afraid of them-let us go quickly on our way as seems good to us and not worry about what they may or may not be thinking. When you are ready to publish your book on Walt it must come out no matter what anyone says - that book is Walt just as much as the Leaves are. Walt will not hurt Walt. Let us keep perfectly cool. England may look after herself. We will look after ourselves." (January 21, 1893)

This, Traubel told Wallace, he thoroughly endorsed, adding: "It seems queer that Carpenter has allowed himself to be bothered about such a thing just as it seemed queer to me that Symonds should have had to suffer from some report which came from Carpenter." Here again, Traubel seems not to have understood the shared concern feeding the fears of the English Whitmanites.

In February, 1893, Traubel relayed to Wallace Daniel Brinton's views "on the question of 'homosexuality." Brinton was a professor of archaeology and linguistics at the University of Pennsylvania who had enjoyed long talks alone with Walt in Camden. Whitman said he was "what I like (in the best sense) to call adhesive: a good comrade, a ripe intellect." ${ }^{27}$ On the basis of this comradeship (and perhaps because of 
Brinton's professional background), Traubel raised with him the "question" of Whitman's homosexuality. Brinton's response was:

I was staggered by the compound, "homo-sexuality," and don't rightly know its connotation; but if it is something sexually abnormal - as it sounds - for heaven's sake let us keep away from it. It would be meat and drink for the decriers of W.W. to learn that this too is suspected to be one of his inspirations. They would substitute for "satyr" another word beginning with $S$ and derived from Hebrew instead of Greek.

\section{The following month Brinton wrote again saying:}

I did not know that it was Symonds who spoke of W. W.'s "homosexuality." The matter now looks clearer. Symonds has been for years bathing in the tank of Italian poetry, which is deeply impregnated and corrupted with abnormal sexuality; and he is on the look-out for it everywhere. ${ }^{28}$ If "Children of Adam" had been written by an Italian poet of the Renaissance, Symonds would have been justified in his suspicions. But with W.W.? No. (February 8, 1893)

In this instance Traubel appears to have welcomed Brinton's opinion, though in general he believed him too intellectual, which, he thought, kept him from fully apprehending the meaning of Whitman's poems. R. M. Bucke shared this same failing, he confided to Wallace, and, though he claimed not to "blame" him for it, he "lament[s]" the "fanatical" in Bucke. "He lives off there alone and fails to see the world factors which perhaps do the most for our expanding civilization," Traubel tells Wallace, adding, somewhat dissociatively:

He has not half the respect that he should have for woman. His wife is herself narrow and dull and he sees all women in her likeness. Walt always found his finest specimens in women and Bucke fails altogether to see the enormous life that opens up through the female nature. His conception of C. C. [Cosmic Consciousness] is limited by this fact sharply and by that other fact of his deficient imagination. He has his theory in intellectual grasp but misses his best phenomena by not having [the] eye to see it." (October $26,1893)^{29}$

Obviously, among Whitman's early followers questions of sexuality loomed large and involved more than just homosexuality. The subject encompassed the very nature of the female and the male, and the need to develop one's sexual nature fully, to comprehend both sexes within oneself if possible, or, at least, to appreciate both. Yet even this raised suspicions, for what made Whitman so personally appealing to some- his female side with its mothering tendency-created as many questions in the minds of others as did the "Calamus" poems. Nor, as we know, was it "Calamus" alone, and its philosophy, that came under fire. Indeed, Traubel gives Wallace a wonderful account (humorous today) of the kind of reaction Leaves of Grass could arouse in Victorian America, even in a liberal audience. Near the end of March, 1893, 
Traubel and Harned attended a Liberal League meeting in Philadelphia and there debated "Mrs. Crompton's paper on 'The Moral Influence of Certain Writers." Traubel describes for Wallace an "exciting little episode" that occurred during the meeting:

A skeptic calls out to Harned to read "A Woman Waits for Me" from the platform. I jumped up and called out, "Read it, Harned! If you don't I will." But Harned did not read, in fact, a gentleman says that perhaps the audience does not wish it. When it came my turn to speak the questioner was again on his feet. "Mr. Traubel, read the poem!" I faced the audience, "Shall I do it?" I asked, adding, "There is no poem in the book I should hesitate to read." But they called out to me to "speak" and let the reading go. When I said, "Did it ever occur to you that the reason it is impossible to read such poems in an audience like this is not because there is evil in the poems but because there is evil in you and me?" This brought down the house with applause. Said Bucke later, "My blood was up." (March 27, 1893)

Besides the sexual, there were other aspects of Whitman's personality that came under public scrutiny in these first years after his death, even from some of the faithful. At a literary dinner held in Philadelphia, someone identified by Traubel only as "Swinton" (actually John Swinton) gave a speech about Whitman which "disgusted" Traubel, Harry Bonsall, and John Burroughs, all of whom, according to Traubel, had expected "more serious knowledge of Walt." ${ }^{30}$ Instead, Swinton dwelt on Whitman's desire to "puff" himself and claimed that "the Mother was like the son, 'gaseous and watery," that Walt lacked a sense of humor "and did not know a joke from an abstraction." The best part of the speech, Traubel reported, was "a letter from Walt to his mother which he read with considerable humor and sense." But Traubel goes on to point out that Swinton's "real caliber" can be seen in the fact that "although this is one in the series [of letters] we are about to print he positively declined to let me use it" (June 5, 1893).

John Burroughs too was troubled by Whitman's "self-advertising," according to an account of a letter from him to Traubel which the latter supplied to Wallace in December of 1893. "He seemed inordinately fond of praise," Burroughs is quoted as writing; "His self-advertising was a shock to many people. I myself would have had him above that sort of thing, tho' I see how it came about. When he retired into himself and wrote his poems he was a god; when in his idle moments he faced the indifference of the public he was often a child" (December 18, 1893). Wallace was angered by this and wrote Burroughs a stern letter pointing out that a word from him, as Whitman's earliest disciple, carried more weight than from another. He concurred in the matter of Walt's love of praise, but insisted it was only because such praise indicated to Walt that he had succeeded in winning "sympathy with his ideas." Further, "it partly-however slightly — assuaged the fierce hunger for sympathy and comradeship which was all the more fierce because it was denied 
proper nourishment throughout his life. What a solitude was his!" (January 1,1894$).^{31}$

In the summer of 1893 Traubel's letters to Wallace dealt heavily with the lawsuit brought against George Whitman by Whitman's former housekeeper, Mrs. Mary Davis, for payment of expenses incurred on Whitman's behalf. From his bitter accounts of this and the way in which he turned on Mrs. Davis and her foster son, Warren Fritzinger (Whitman's nurse), it is possible to glimpse a side of Horace Traubel not apparent in the record of his conversations with Whitman. ${ }^{32}$ As was later the case in his relationship with Wallace, Traubel seems to have been inclined toward jealousy, especially of young men whom Whitman liked or admired. Furthermore, he was a man of strong opinions, even about those in the Whitman circle, and he expressed some of these to Wallace. We have already seen his opinion of Bucke, Brinton, and Swinton, and he did not stop at literary convictions. ${ }^{33}$ Of J. W. Alexander's 1887 portrait of Whitman, he says: "Alexander's portrait (?) of Walt hangs in a very prominent place in the Metropolitan. It is humbug. It is not $W . W$." (June 2, 1893).

Literary judgments were needed, however, when J. A. Symonds's book-length study of Whitman arrived in May of 1893. It came just weeks after word of Symonds's death from the tuberculosis he had suffered for years. "I am inexpressibly pained to learn that Symonds yesterday died in Rome," Traubel wrote to Wallace on April 20, 1893. Then:

Another light gone out - another soul mysteriously washed to sea. My heart is too fulltoo full. Symonds was dear-dear to Walt and dear to me. I have written him and had his love now for years, and it is with no slight pang that I today think of him as dead and silent. Well, well, well- one by one the pages of the book are turned. The eye watches and fills and the blurred letter holds its secret psalm. Loving and true, true and loving, this man used his genius for the best service of his fellows. I do not feel broken off from him. I am more than ever his lover-more near, more near!

It is understandable, then, that the arrival a short time later of Symonds's Walt Whitman, A Study called forth a rush of emotion; "I shall hold it sacred till the day I die," Traubel wrote Wallace. Of the author he says, referring to Symonds's years of illness, "Brave hand, to have fought off destruction with so steady a nerve and for so many years of threat and labor!" Admitting that he has read hardly any of the work, Traubel still cannot resist some judgment, "I am not fully persuaded that Symonds has written a great or final book about the old man and his intentions and results." He hopes to be proven wrong, however, and so concludes with, "And I love Symonds, for his warm welcoming, receptive soul" (May 4, 1893).

Two days later he was ready to render a verdict: "It is not a brilliant book. ... Symonds directly says he does not regard W. as a genius of 
the first class - that genius is certain, and Walt was not-but here again he fails the truth, which is that Walt was certain tho' willing to admit the temporary doubts." Traubel continues his critique:

After all, a man seems to need to be born a democrat in order really to espouse democracy. No amount of loving can undo the damage of the schools. Symonds always allowed that he had been wounded and that the sore had never healed. I think his book will do a vast good among scholarly people. It's a hand leading to Leaves of Grass. (May $6,1893)$

Being "born a democrat" meant not being born into the English upper class, as Symonds had been, and the reference to damage done by schools-while it may well have included, even unconsciously, English public school buggery-seems more likely to reflect Symonds's admission to Traubel that his "aristocratic" connections and literary education had made it hard "to break the conventional husk, and be as simple as God made us." 34 Since none of Symonds's known letters to Traubel speak of the sexual experiences at Harrow recounted in his memoirs, the "wound" Traubel refers to apparently was "the burden of book learning," which Symonds lamented having to carry about with him, from youth, as a result of his intellectualism. For his part, Wallace agreed that Symonds's book was "not specially valuable except as a study of Symonds. To us, I mean" (May 16, 1893).

Traubel's grief at Symonds's death in April was no doubt intensified by its proximity to the first anniversary of Whitman's death. As that March date approached he had addressed his letter to both Wallace and Johnston:

The year has gone quickly. I see myself back in old scenes and live in the past again. The world brightens for me as the days pass and I seem to flow out ever on new streams past the haunts of forms of men and the wildwood of the unsettled worlds. Every day it is Goodbye! to something and Goodhail! to something other. . . . Tomorrow will be full of sorrowful memories and yet there is no danger that my soul will consort with gloom. The great cause that holds us - the great cause of the freedom of man and his cosmic enfranchisement-arrests or baffles all evil resolves. As we go into the new year-out the decrepit portals of the dead cycle-my own heart grows great in heroic feeling! I have it not in me to say more today. With this I reach my hand. You can hear the beating of my heart. Our aim is one-our fealty is not a bauble or a bubble. (March 25, 1893)

The great cause, "the freedom of man and his cosmic enfranchisement," to which Traubel claimed he and his fellow Whitmanites were committed, was not so clearly delineated in their minds as his effusions would imply. Given the vagueness of the term "cosmic enfranchisement," it is not surprising that differences in understanding would have arisen, but the indications are that these differences were more than semantic and had to do, in part, with political and sexual interpretations of Whitman's philosophy of democratic comradeship. As Paul 98 
Salveson has shown, J. W. Wallace, Dr. John Johnston, and others of the Bolton group were part of what Salveson terms the "socialist culture" of late nineteenth-century England, and the definition they most often supply of "the cause" is "liberty and progress," which they believed Whitman personified. ${ }^{35}$ Edward Carpenter, an avowed socialist, claimed Leaves of Grass for the English movement by linking socialism to Whitman's call for a radical democracy that would break down the class system and usher in the age of a union of individuals who had achieved the highest level of comradeship. Symonds, as we have seen, had his own point of view to advance, which he drove forward almost unrelentingly. J. W. Wallace tried to explain it all to Traubel by saying that no one understood the true nature of the forces "leavening the social framework of this country. It calls itself 'Socialism.' Yet this word doesn't express it, nor is the theory of government which Socialism means that which it makes its aim. It is rather the prenatal struggle - the slowly arriving consciousness of Democracy" (July 19, 1892).

Though Traubel later embraced the socialist cause, especially in his writings for The Conservator, he was never a member of the Socialist Party in America. Further, in his letters to Wallace and Johnston, written in the early years of socialism, Traubel vigorously argued against this philosophy, insisting that his faith lay with the "individual," a faith which he grounded in Whitman's "personalism" and in his own distrust of "governmental mechanism." "I6 "I would on no account destroy the individual," he tells Wallace; "The state is an evil which so far has made war and given privileges to either one man or a class of men. I believe in perfect freedom. . . . No States, Freedom-Freedom to act and speak, freedom to plant and reap, freedom to reach the highest personal duties and powers. Given the light as Walt brought it, men will learn to take care of themselves" (January 17, 1893).$^{37}$

Recognizing in this the voice of the anarchist, Wallace so charged him, causing Traubel to declare, "I would rather be an anarchist than a socialist-that is, would rather believe in man's safety minus the state, at last free and loving" (April 5, 1893). Wallace gently chided his American friend for his "lectures" on individualism but was not able to deflect them, and Traubel continued to describe himself for some years as "an extreme individualist." In 1895 he told Wallace, "I am heartily a Liberal in English politics. . . . I do not like the state. I would not increase the powers of the state. Man needs to be let alone. He will take his proper place when the way is open. ... Let us believe in man and honor his impulses. Beneath the supposed politics is the fire. Ever it burns. The flame is steady and is eternal" (February 2, 1895).

The sexual interpretation of Whitman's democracy of comrades fostered by Symonds and Carpenter was the sticking point for Traubel, Bucke, and others among the American Whitmanites. No matter how carefully Symonds couched it in his study of Whitman, or how he tried 
there to hedge the poet's personal reputation from harm, it is hard not to see how exultant he was at the prospect of a new justification of homosexual love, one which, in its emphasis on the "natural basis" of this affection eliminates "classical associations of corruption" and ignores "the perplexed questions of a guilty passion doomed by law and popular antipathy to failure." 38 Traubel could not accept this as a valid interpretation of comradeship and chose to blame Symonds's upper class origins for his inability to understand Whitman's democratic teachings. Facile and insular, Traubel's view of Whitman's American innocence beset by European perversity reduced their differences to an almost provincial level, but it was probably a more comfortable level for Traubel because it allowed him to dismiss the seriousness of Symonds's challenge.

In July of 1893 a son was born to the Traubels and named Wallace, in honor of J. W. Wallace. Perhaps the name would have been Walter if Harry Fritzinger (Warren's brother) had not named his boy for the poet shortly before Walt's death. ${ }^{39}$ The following year Thomas Harned, who, Traubel said, "hates Camden," moved to a large estate in the Germantown area. Traubel, however, loved Camden-“It was Walt's place," he told Wallace. In March of 1894, Traubel was working feverishly to reconstitute the Walt Whitman Fellowship into an international organization. And on March 29, 1894 he defended Edward Carpenter's pamphlet Sex and Love, saying "it is Carpenter who is clean and his despisers who are not." Surprisingly, these two seemingly disparate issues, the Walt Whitman Fellowship and Edward Carpenter (and the homosexual lifestyle he represented) combined to create a breach in the warm relationship between Wallace and Traubel.

Traubel's desire for a worldwide organization of Whitman lovers was natural for him. He was an organization man who had founded the Philadelphia Contemporary Club and was a founding member of the Philadelphia Ethical Culture Society. Excited about this new venture, he wrote of it frequently to Wallace, who did not share his enthusiasm. In fact, Wallace's silence offended Traubel, who continued to push the matter. In August of 1894 their differing views came to a head over a proposed $\$ 2$ annual membership dues which Wallace claimed was exorbitant for the poor in England who, he claimed, often voluntarily impoverished themselves in the interest of the socialist and/or Whitman cause and must not be excluded. (A month later Traubel quoted to him Isaac Hull Platt, another American Whitmanite, who accused Wallace of establishing "an oligarchy of the poor.") Furthermore, Wallace believed that all publication should be through the normal channels and not from the Fellowship; only Leaves of Grass should be offered, "no interpretations."

Traubel was insulted by these comments, but his reactions were intensified by other emotions occasioned by an earlier string of events. 
Perhaps, in light of later developments, it is best to date these events of the summer of 1894 from June 2 when an Alfred W. Beville of Hampstead Heath, London, wrote to Traubel saying he was interested in joining the Fellowship, which he appears to have learned of from Edward Carpenter, who was, he said, "the only influential Whitmanite" he knew. By the end of August, Beville was offering himself as the London representative for the Fellowship, but hoped that it would not prove too costly to continue since he was "only a hired labourer." Beville always remained on the outer limits of the Whitman circle, but he was at this time evidently a friend of Carpenter, who, like Symonds, often cultivated such laboring class friends as homosexual lovers. In any case, it appears from his comment that Beville was privy to the discussions about Fellowship dues. Later, another comment, this time about Whitman, and reputedly made by Beville, who never knew the poet, contributed to Traubel's distancing from his English friends.

It is hard to tell just how aware Traubel was of Carpenter's homosexuality, but he seems to have been alternately critical and defensive of the man, just as he was with Symonds. In July Wallace had felt the need to defend Carpenter to Traubel: "Don't make any mistakes about Carpenter! . . . he loves and honors you. There are temperamental and other differences between you-between us all. But at bottom we are One. And love (not critical analysis) apprises us of the fact. So love him and love me as best you can for we both love you - good heavens! how I love you!" (July 28, 1894). This was not the first time Wallace had taken the role of mediator between Carpenter and Traubel. In May of 1892 he praised Carpenter's Towards Democracy, which Traubel thought derivative of Whitman, saying: "Perhaps my knowledge of the forces within English life and society with which Carpenter does battle help me to realize the quiet heroism of his life and work more than is possible to you in your environment over there" (May 16). In the months after that, in 1892, Wallace so repeatedly wrote praises of Carpenter, his person and his work, that Traubel became even more critical. In September of that year Wallace became aware of his excesses in this regard and apologized for going on at such great length about his friend.

Returning once again to the summer of 1894, however, we find that in July the famed Socialist orator Caroline Martyn was taking a well-earned rest at Wallace's home. Visiting at the same time was Philip Dalmas, an American composer and singer from Philadelphia who was part of the Whitman circle there and a friend to Traubel. Judging from the way in which Wallace wrote of this young man, one can only say that he fell in love with him; indeed, Dalmas seems to have had that effect on many people, including Edward Carpenter (whose first meeting with him was at Wallace's home during the summer of 1894) and Charles Sixsmith, a disciple and loving companion to Wallace who lived 
not far away..$^{40}$ Even Dr. Johnston seems to have fallen under his spell, for he appended a note to one of Wallace's letters to Traubel saying, "Dalmas is an indescribably lovely and loveable man" (August 7, 1894). On July 28, Wallace informed Traubel that Dalmas had left Bolton and would sail from Hull for home later in the year. "I believe," he continued, "I shall have to interpret him to you fellows! For not one of you ever prepared me for what I now know of him and love with all my heart. Is it possible that you folks do not know him?"

This indeed was the question, though put more specifically: Did Traubel know Philip Dalmas? Certainly he knew him from the Whitman Fellowship, to which he and his sister Caroline belonged. And the evidence of letters from Dalmas to Traubel now in the Library of Congress is that prior to his visit to England, Dalmas was very much in love with Traubel, something of which Traubel could hardly have been unaware. The letters speak of this love clearly, and in language that goes far beyond what was common in letters between Traubel and Wallace, or others of the Whitman "lovers." It is, in fact, the language of seduction, which may have begun in January 1893 with the first extant letter from Dalmas. In it he invites Horace and Anne to visit his studio, promising to sing for them. "Tho' there exists that saying about three not being company, yet I wish to have it three for you two are one," he begins. He then refers to his physical infirmity, an oft-repeated claim of his, though his photographs, which show a very beautiful young man, give no indication of it: "You must have perceived that this fellow is hampered physically so that at times his real self is not very present." This is followed by a few more self-deprecating comments and then a turn of the page brings the following, with no preparation:

How I love this slave, coward slave, who looks into me and does not despise me because I compass not his [word illegible]. I wonder if it be possible that there (should?) [sic] be anything in me resembling that which I see in him. At thought of him there wells up in my soul that which vainly strives to pour out into the world to show it how great a thing lies in its bosom. I will go to this slave and say be my master for you have shown me liberty-I being only - Dalmas. (January 27, 1893)

By the third of May, Dalmas was writing of how he longed to see Traubel: "Give me your hand loved friend and believe that one holds dear in this heart an image never to be broken by passion, strife, or happening." To this is appended a note that sends love for Traubel's daughter Gertrude, "and to Anne Montgomerie [interestingly, Dalmas almost always refers to Horace's wife by her maiden name] all that I can be to her." Three days later he writes "Beloved Traubel," begging for a visit and bewailing his existence:

It seems simply despicable to be unstrung physically so continuously as I have been through my life, yet I walk on the edge of a precipice and it is unending struggle be- 
tween me and the phantoms for the [word unintelligible] of fate. Oh could you but know me! Could you but know the price of my existence and what each heart stroke costs me. You would behold a [word unintelligible]. You have not dreamed of the mystery that is, and in my heart that loves you so endlessly you have not seen the least of what is. Will you come tomorrow at 423? [S. Broad St., Philadelphia, where his music studio was located] Tell me. O Traubel it is - Dalmas. (May 6, 1893)

Another letter of the same date (either an error or written later in the day) says:

I have resolved to be with you at least five days in June, come what may. I will be with you on some time next week and perhaps late tomorrow. My heart beats high at thought of you: one to whom I may speak of love and be accepted. Near whom my heart may throb out its joy or sorrow, and be recognized. I dare not speak all lest thou and I be consumed in the flames of the [unintelligible.] I may not utter the music of my love for my soul must break in utterance and my throat remain silent therefrom. Like a swan am $\mathrm{I}$, in death, and at the hour of my death all will be spoken, sung, ecstasied, and my heart, so full, break. Then must the world know who has been with it and it will weep o'er the broken dead.

Dare you think or know all, or whom: Dare you let me bring my love so close unto you that you be lost unto yourself, e'en for a moment? Oh, I ask naught for myself! All comes in the vast sequence of the pulsating Universe. And you will come to me wholly, and the sequence of your harsh chord resolving into radiancy is the sweetest of all music in my now dying ears. Dying to attain life. Oh, dost thou know me, - Dalmas? (May 6, 1893)

The question of just how all of this connects to their love of Whitman is answered by occasional references to the music Dalmas is composing, based on Whitman's poems and supposedly expressing America's democracy. Traubel may have deceived himself into believing this musical adaptation of Whitman's words was the true basis of his attachment to Dalmas, though he could hardly have confused the ecstatic language of these letters with that of other Whitmanites, not even those of the effusive Wallace. And since we do not have Traubel's letters to Dalmas, one cannot say for certain that Dalmas was not encouraged in his love. In January 1894 Dalmas wrote, "Your dear words burn in my heart a lasting incense satisfying my lovely moments and your spirit presence cheering me in a work whose definite results may be many a long day off. . . . We are forever intertwined-be life what it may." A concluding reference to Whitman suggests Dalmas believed the poet either did, or would have, shared his feelings for Traubel: "My love to Anne Montgomerie and the dear babies. To yourself, Horace, Walt will say the rest. Would he not love as I love, see as I see? Beloved man" (January 12, 1894).

Having learned from Symonds's book (if, indeed, he did not already know) the role of homosexuality in Greek love, one wonders what response Traubel expected from Dalmas when he wrote him what Dalmas referred to as "the interesting description of the Greek hymns." 
"You seem so like a Greek to me," Dalmas continues, "an ancient one, and I am so transported at times into the [word unintelligible] that I quite forget your present personality. Your sweet voice reaches me from out the air and your song is of my life, for in that world which we together view is my all" (April 12, 1894).

But that was in spring; in summer Dalmas left for England and, after some early letters sent from London, apparently there was no further word. In August his mother, Anna B. Dalmas, who was also a friend of the Traubels, wrote to say that she had had a long letter from Philip explaining that he was not able to write from the north of England, for "his every moment was so filled and so precious." She adds that in a letter to his sister written from J. W. Wallace's home he had said, "Tomorrow we go to see Edward Carpenter, England's brightest soul." And to this she adds what must have been a blow to Horace: "In his letter to me he asks, Did you hear I stayed with Carpenter? then goes to praise of this remarkable man and adds 'he is making a pair of sandals for my very own feet'" (August 20, 1894).

Later, Dalmas traveled to Germany and wrote to Horace about his visit to the Black Forest and how "Europe has much to give. Much to teach, yet that which we look for in America must come from her alonefirst. I am not held by what is here. I am held by America. I am closer afar off" (October 2, 1894). No doubt the words reassured Traubel, for, back once more in the home of Dr. Johnston in Bolton, Dalmas wrote to him:

Had you thought me indifferent? Had you forgotten my avowals? They have been inscribed for eternity, for the beginning was not when we met. Oh how my eyes dwelt upon you when first we met, personally, I realizing the man. A man of truth, with vision filling the utterances universal. Behold me with you now close and close, quite nothing twixt us and I the simplest of all know you oh so perfectly. There is so much to say yet I must leave you to fill the blank spaces. . . . Not a fresh note has been put to paper. . . . Forget space-come to me and remain." (November 10, 1894)

Between Germany and Bolton there had been a brief stay in Hampstead Heath, where Beville lived, and a letter to Horace from there assured him: "The sound of your voice thrills through my heart in tones such as may not sound abroad. In the stillness of my being I know you. Thou and I together. I gaze upon you and am filled and in my gaze you can read you in me." But the differences between Europe and America evidently had intruded upon their idyllic oneness, for Dalmas breaks out, "Let them have their countries, castes, kings, ships of war and all that pertains thereto, but let me have you and let me behold that significant look and hear that word which is more than the speeches of a thousand premiers" (October 31, 1894). The Englishmen, he says, are there with him as he writes, and they sing out "Oh America! Pioneers 
and Pioneers!" He will be home soon; he is full of good cheer and love, but signs the letter formally - for the first time- "Philip Dalmas."

Nothing more was said of Dalmas in the letters between Wallace and Traubel, nor of the Whitman Fellowship until the blow-up over the matter of dues. In between, there had been Traubel's criticism of Carpenter (this letter is not in the Wallace file) and Wallace's defense of him. In the months following Philip's return to Philadelphia his correspondence with Traubel was sparse and related mainly to matters having to do with the Fellowship and meetings, many of which Dalmas said he could not attend. Dalmas returned to Bolton in June of 1895 and, after spending a few days with Wallace, he went on to Carpenter's home in Sheffield. Wallace wrote to Traubel: "In the perfect seclusion and quiet of the beautiful valley there he will have full opportunity to develop in his own way-as the inner impulse directs" (June 22). Though Wallace may have meant by this a reference to Dalmas's composing, it seems more likely he was attempting to convey to Traubel Philip's impending sexual breakthrough.

Dalmas remained with Carpenter until March of 1896 when he decided to go to Paris. This decision must have been made by November of 1895, because in that month Dalmas wrote Traubel a truly remarkable letter too lengthy to be quoted in full here. Written from Carpenter's home, it bears no salutation and devotes pages to an explanation of why he had not written since he left America five months earlier. In truth, there is no reason, he says, other than the fact that what he had to say would hurt and anger Horace and so, in cowardice, he had avoided writing. The shadow of the trial of Oscar Wilde (begun in April 1895) seems to fall across the page as Dalmas adds, "in these days of subtle reasoning one's declarations of love can be turned into engines of hate by the loved one's lofty conception of what life is and since the unnatural has gone out of fashion, I suppose it to be perfectly natural that you should hate me, by this, seeing that hate is just as good as any other useful quality and brings just as much happiness, I suppose, as the love we so foolishly crave."

The letter is a long, prolix statement of defense for Dalmas's decision to remove to Europe. He insists that in so doing he has not abandoned his original purpose, to write "a music to be of the purest democracy and on such broad and splendid lines as those on which Whitman founded his literature and poetry of the States." He has felt for some time that Traubel had "lost interest" in him because he had not produced this music, and now, to see him "fly from my country and friends to grasp at something here far less than America holds," must, he realizes, have disappointed Horace greatly. ${ }^{41}$ But, he says, "I have not the slightest wish to plead myself back into the original regard you held for me nor the slightest desire to have you approve of my course in life or work. The individual must quench that thirst at such a spring as con- 
tains the quenching draft." One can only conclude from this that while Traubel may have encouraged Dalmas's affection, perhaps even used the proposed musical transcriptions as a shield behind which to hide their mutual attraction, he had not been the spring at which Dalmas could quench his passion.

Having declared his independence of both America and Traubel, Dalmas criticizes his country for its "forced enthusiasm" and "big talk," sparing not even Traubel's Whitman Fellowship International, which, despite his enclosure of the $\$ 2$ membership dues, seemed to him "such a commercial affair a mighty hullabaloo about a man who comes really and permanently only in the great silent moments of our lives."

Dalmas's desertion was only one of the troubles that haunted Traubel during the difficult year of 1895 . The year began with the trial of Oscar Wilde in England. "How awful, tragic, baffling, this matter which has engulfed Wilde!," Traubel wrote to Wallace on April 8, 1895. "I have a fine letter he once sent Walt. Brinton knew him well from his visit to this country. They met, of course, in Philadelphia, and it was often. 'No trace of the disease then,' says Brinton." In May, at the dinner in honor of Whitman's birth, Harned read a paper written by Bucke, who could not attend, "Was Walt Whitman Mad?" The paper made no direct reference to sexuality, though it did project a note of defensiveness on the subject of the poet's morality. A short time later Traubel had a letter from Bucke in which he discussed Edward Carpenter's latest pamphlet, Homogenic Love (1895). He told Traubel of a claim made by Alfred Beville in Hampstead, London, that in Carpenter's correspondence with Dr. J. Johnston of Bolton, Carpenter had endorsed "sodomistic practices," adding that "Walt himself is to be construed in the same sense." 42 Bucke insisted to Traubel, "the charge is indefensible of justification" (June 13, 1895).

One wonders just how great a shock this charge could have been to Traubel, who by this time must have expected something of the sort from across the ocean. What probably pained him the most was to learn in this roundabout way of things that were being said in England which could prove especially damaging to Whitman in light of the Wilde case. And all of this came at just the time Philip Dalmas was leaving America a second time, for England and Edward Carpenter. Seeking comfort, no doubt, from a fellow American, Traubel turned again to Daniel Brinton for an opinion on the matter, and the following day he wrote Wallace about the rather startling response he had received: "Brinton's suspicion of W. W. is to the same effect. It is damnable. I have Walt's own denunciation of the matter. It was frequently urged upon him by Symonds that he should declare himself in plain prose upon the matter, and once he did so, in unmistakeable terms. I have his original draft of that letter." ${ }^{33}$ Perhaps before writing to Wallace, Traubel reread the letter referred to, for the angry denunciations contained in Whitman's 
letter to Symonds are echoed in Traubel's "damnable," the same word used by Whitman. And so the denial was continued.

Clearly cracks were beginning to appear in the wall of defense Traubel was trying to build around the Whitman image, for here was Brinton, one of the disciples, with an opinion decidedly altered from that which he had offered in 1893. Traubel began to retreat from the issue, and when he did write of it again his tone was considerably less vehement. Like Symonds, Edward Carpenter insisted on hinting at that which Traubel feared, but, after reading Homogenic Love, Traubel's comment to Wallace was a rather feeble one: "Carpenter makes a real mistake if he supposes that Walt had no strong feelings against physical relations between members of the same sex" (June 20, 1895). The following month Carpenter sent Traubel a copy of his pamphlet. Though pleased to have it, Traubel expressed to Wallace a wish for "some explication" that would circumvent "the difficulty of making a statement on such a question in the prose of the markets" (July 18, 1895).

It is hard to say for certain, but it appears that Traubel was beginning to hope for some way out of the dilemma that would prove satisfactory to the doubters while at the same time not running the risk of offending public morals - or the Whitman disciples - in America. That the latter was a major consideration can be concluded from the reaction of W. S. Kennedy to Symonds's study of Whitman. Kennedy set his objection in the context of American innocence vs. European decadence by declaring, "We here in America were astounded that it seemed to him necessary ... to relieve the Calamus poems of the vilest of all possible interpretations. It was a sad revelation to us of the state of European morals, that even the ethical perfume of these noblest utterances on friendship could not save them from such a fate." ${ }^{\prime 4}$ In May of 1895 Daniel Brinton had refused to stand for reelection as president of the Whitman Fellowship, citing as his principal reason the change that had taken place in the interpretations of Walt Whitman's life and work, changes in what he held to be "the spirit of Whitman's teachings." Though he declined to be specific as to what these changes were, Brinton concluded his letter with, "I do not want Whitman destroyed for me." 45

Nothing more was said of the burning issue of Whitman's sexuality in Traubel's letters to Wallace, but suddenly on August 11, 1895, he tells him:

Pete [Doyle] now lives in Philadelphia and I come across him occasionally. He once called on me. Inclined to be reticent about himself at first, but soon opened up joyfully and confidingly. His love of Walt is in no way diminished. When he speaks of it his eye is often dimmed with tears. But he is manly and his sorrow is wholesome. Symonds could not have divined the sort of man Pete is, else his description would have been conformable. He is in no way coarse and commonplace, is in a way interesting and in many ways strong. 
To this he adds the news of Bucke's plan to publish Whitman's letters to Doyle, and it seems likely that he and Bucke viewed this publication as a means of eradicating any doubt about the nature of the relationship between Walt and Pete. Symonds, who had described Pete as "artless and uncultured," referred to the correspondence between the two men as an example of "democracy," an example which he claimed to have followed by enjoying the company of members of the European working class as his equals. ${ }^{46}$ What he neglected to add was the fact that many of these democratic friendships were with sexual partners, such as his Venetian gondolier, Angelo Fusato.

There is no clear indication that Traubel knew of these relationships, only that he saw in Symonds's evaluation of Doyle another instance of his misunderstanding of democracy. Nor is it clear that he held Wallace responsible for the relationship that developed between Philip Dalmas and Edward Carpenter. What is clear is that for the first time since he began his correspondence with $\mathrm{J}$. W. Wallace in the wake of Whitman's death, a correspondence that he maintained on an almost daily basis, he - and Anne-ceased all communication with Wallace in September of 1895, two months after Dalmas's departure. For the remainder of that year no word came to Wallace from his beloved friends in Camden, not even at Christmas. Then came a New Year's greeting, "Dear brother mine: greetings manifold and unalterable love! Traubel." Nothing followed, however, and Wallace wrote again and again-entreating letters showing obvious distress. Strangely, there is no reference to a possible illness in the Traubel family that might be construed as the cause of the silence; Wallace seems to suspect otherwise, but refuses to acknowledge there could be any reason for serious differences between them. Finally in mid-January of 1896 he suggests that "Possibly something said by another-something unwise and untrue" is the cause, and he again declares his undivided love for Horace and Anne. The silence was not broken again, however, until the end of January, when a small packet of letters arrived with little word of explanation.

The subject of Whitman's possible homosexuality does not appear again in Traubel's letters to Wallace, and one wonders what mental disposition he made of it that settled the matter for him, or if he simply decided to stop defending Whitman on this score. (One wonders as well if some of the entries in the "two very interesting" journals he inherited in the three-way division, in the spring of 1895, of Walt's papers, played a part in silencing him.) More immediately, if - as the letters from Philip Dalmas indicate-Traubel had allowed himself to be the object of a same-sex attachment with a member of the Walt Whitman Fellowship, then his main concern would have been for Whitman's reputation, especially in America, and he would have feared the potential for damage to that reputation from Dalmas and the band of English admirers. 
Traubel seems to have maintained a willful innocence (or denial?) with regard to Whitman's sexuality, which for a long while he extended to include some of those who were, in his purified use of the term, Whitman's "lovers." Perhaps, prior to Dalmas's defection, the ocean that separated him from the Bolton group and other Whitmanites in England served as a welcome buffer isolating him from a full knowledge of the various relationships that existed among them. He never met Charles Sixsmith, the close friend of Wallace and Johnston with whom he also corresponded, and may not have known of his bisexuality, his closeness to Carpenter, and the love affair he too may have had with Philip Dalmas. ${ }^{47}$ It may have been that he really did not want to know these things, preferring a father/son relationship with Wallace that replaced the one he had enjoyed with Whitman, with no threat from possible "siblings." In March of 1896, after a three-month silence, Traubel talked of visiting Wallace, who was ecstatic at the prospect. "Foolish fellow that you have been!," he chided; "To think that any other could usurp your place in my heart! And you have actually been inclined to think that! Come and see!" But Traubel never went, nor did he ever resume the habit of writing almost daily to Wallace.

The man to whom he addressed one thousand plus letters was himself something of a sexual enigma, in that he never married but maintained a "spiritual" relationship with a woman from 1893 to his death in 1926, all the while remaining the object of an adulation bordering on worship from men his age and younger. ${ }^{48}$ Possibly it was the fear of having to acknowledge something about himself that kept Traubel from admitting Symonds may have been on the right track in what he discerned in the "Calamus" poems. One cannot help but think that Wallace's comment about Philip Dalmas-"Is it possible that you folks do not know him?"- may have applied just as well to the man with whom Traubel had spent part of every day for at least four years. Traubel can be forgiven, however, for his persistent denial of the implications of "Calamus," which were so apparent to his English counterparts, for he believed in Whitman's American "innocence" in the same way he believed in his American "individualism." Nor was it entirely necessary for Horace Traubel to have wrestled with the ghost Symonds saw, for it was given to him to play another role in the final years of Whitman's life and immediately after, and he played it well.

\section{Hofstra University}

\section{NOTES}

1 Traubel often refers to Wallace as "lover," as in "Ever, o good man and lover mine." His letters are usually signed simply "Traubel," or "T." Wallace originally addressed his letters "Dear Traubel" but in 1893 began to write "My dear Horace" and signed himself "Wallace." 
2 Harold Blodgett was the first to tell the story of the Bolton admirers in Walt Whitman in England (1934; rpt., New York: Russell \& Russell, 1973), 212-215.

3 J. Johnston and J. W. Wallace, Visits to Walt Whitman in 1890-1891 (1917; rpt. New York: Haskell House, 1970), 89. This account also records the founding of the Bolton group.

4 The letters from Traubel in the Central Library, Bolton, total 1,061. The breakdown of letters and years is as follows: 1891,$6 ; 1892,94 ; 1893,309 ; 1894,240 ; 1895$, 315 ; 1896, 43; 1897, 3; 1898, 13; 1899, 2; 1900, 1; 1902, 1; 1903, 4; 1904, 3; 1905, $2 ; 1914,1 ; 1916,1 ; 1918,3 ; 1919,20$.

5 Wallace maintained a separate correspondence with Anne Traubel, Horace's wife. Both sets of letters are contained in the Library of Congress Manuscript Division.

6 There is an interesting juxtaposition of father and son figures here, with Traubel echoing the words of the Biblical David mourning the death of the young man he loved as a son (2 Samuel, 18). Further, Absalom built a sepulchre for himself because he had no child to provide one; could Traubel have been thinking of Whitman's tomb in Harleigh Cemetery?

7 The letter, dated August 10, 1891, appears in Richard Maurice Bucke, Medical Mystic, ed. Artem Lozynsky (Detroit: Wayne State University Press, 1977), 161.

8 Traubel, With Walt Whitman in Camden, Vol. 9, ed. Jeanne Chapman and Robert MacIssac (Oregon House, CA: W. L. Bentley, 1996), 7.

9 Whitman's letter to Kennedy of August 20, 1891, refers to Bucke's letter and simply says "Which I will lend you to be return'd to me" (Kennedy, Reminiscenses of Walt Whitman [Paisley, England: Alexander Gardner, 1896], 68). In his letter Bucke says to give "this" to Traubel for safekeeping and not allow it to be copied. The Record's story, with a London byline, carries no "direct quote" (as Traubel claims), but does attempt to rectify a view of Tennyson as hostile recluse by pointing out (via Bucke's description of his visit, though without identifying him) that visitors were welcomed. The Record writer may have simply picked up this information from the earlier Transcript story.

10 Wallace had earlier (August 4, 1892) criticized Kennedy for including "newspaper talk and gossip" in what he was planning to publish on Whitman in Reminiscenses.

11 In March of 1893 Traubel wrote to Wallace: "My George Whitman article will interest you some. And yet it makes no new revelations. George of course never had the least idea that he had a big brother." The ten years between the births of the two meant that Walt was already working as an apprentice printer by the time George was a boy.

12 Childs's refusal is interesting in that he had made Whitman a loan of $\$ 500$ toward the purchase of the house, a loan which Gay Wilson Allen says Whitman repaid. See The Solitary Singer (1955; rpt. New York: New York University Press, 1967), 515. Traubel's anger with W. S. Kennedy may have been fueled by the latter's response to the solicitation: "I don't want that old shanty perpetuated and don't think Walt would" (undated letter to Traubel). Kennedy wanted a statue of Whitman in Manhattan, claiming he was "only an exile in Philadelphia" [sic].

13 Symonds explained at the time that English men of letters averaged very little income per annum. See his letter of November 23, 1892 in The Letters of fohn Addington Symonds, ed., Herbert M. Schueller and Robert L. Peters, Vol. 3, 1885-1893 (De- 
troit: Wayne State University Press, 1969). Subsequent references will be to letter numbers in this volume.

14 Letter No. 2053.

15 Letter No. 1814.

16 Letter No. 2065.

17 Uranianism was but one of a variety of forms derived from the coinage of Carl Heinrich Ulrichs, "Urning," a term he used to refer to homosexuality in a series of pamphlets in the 1860 s.

18 J. A. Symonds, Male Love, ed. John Lauritsen (New York: Pagan Press, 1983), 80. One of the reasons Symonds refrained from public use of the word homosexuality was because Krafft-Ebing used it in his Psychopathia Sexualis (1886) and he disagreed with Krafft-Ebing's belief that sex was perverse if not used for reproductive purposes.

19 Letter No. 1867.

20 Letter No. 1814.

21 Letter No. 1822.

22 The discrepancy is pointed out by M. Jimmie Killingsworth, "Walt Whitman's Pose and the Ethics of Sexual Liberation," Walt Whitman: Here and Now, ed. Joann P. Krieg (Westport, CT: Greenwood Press, 1985), 75.

23 Letter No. 2088.

24 Letter No. 2079.

25 Letter No. 2079.

26 Symonds, 97. The same phrase, “omitted to perceive," appears in Symonds's study of Whitman.

27 Quoted in Allen, Solitary Singer, 506.

28 Symonds was the author of a seven-volume study, The Renaissance in Italy (18751886).

29 On September 8, 1892, Anne Traubel had written Wallace a critique of Bucke; Wallace responded to Horace Traubel that Bucke would never fully reveal his thoughts to Anne or to any woman as he had to him (Wallace) in a series of talks the two had when Wallace was in the States.

30 Burroughs identified Swinton to Clara Barrus in 1907; see Barrus, Whitman and Burroughs: Comrades (Boston: Houghton Mifflin, 1931), 91. Swinton was managing editor of the New York Times and had been very helpful to Whitman in the matter of obtaining George Whitman's release from a prison camp during the Civil War.

31 Traubel was well aware of Walt's tendency toward self-advertising and had raised the matter directly with him, only to have Whitman defend himself as he always did when charged with "puffery." See Traubel, With Walt Whitman in Camden (1914), 3:459-460.

32 For a full account of this, see my "Letters from Warry," Walt Whitman Quarterly Review, 11 (Spring 1994), 163-173.

33 R. M. Bucke wanted to print Leaves of Grass with the poems in chronological order, to which Traubel strenuously objected. "L. of G. must not be edited," he wrote, 
"W. W. sought to prevent any later reordering by shaping it in its final form before death. The poems are in spiritual sequence, and he knew it" (July 4, 1893). Not even Whitman was safe from criticism; Traubel once wrote to Wallace, "I wish My Captain was with the dogs! and a plague on all the formalists!” (January 12, 1893).

34 Letter No. 1867.

35 Loving Comrades: Lancashire's Links to Walt Whitman (published by the author in conjunction with Bolton Branch of the Worker's Education Association, 1984), 2. A revised and updated version of this essay appears in this issue of the Walt Whitman Quarterly Review.

36 Salveson, 3. Allen calls Traubel's "a rather mild and vague socialism" (Solitary Singer, 532), but the letters reveal him, at this stage, to be quite strong in his rejection.

37 On July 4, 1893, Wallace wrote, "American Independence did not really and fully begin till Walt inaugurated it. Now it really exists as it never did before." An interesting sidelight on Traubel's politics is his espousal in February, 1893, of the movement to annex Canada. According to the letters, he and Bucke agreed in this (claiming Whitman's spirit of no boundaries as their ground), and they expected to see it happen within the next decade, with England making no complaint. William English Walling, Whitman and Traubel (New York: Albert and Charles Boni, 1916) traces Traubel's political development after Whitman's death.

38 Symonds, Walt Whitman: A Study (London: Routledge, 1893), 84.

39 Of the Fritzinger child nothing is known, but Wallace Traubel died of scarlet fever on February 27, 1898.

40 Dalmas seems not to have returned Wallace's affection, since in a Christmas 1894 letter to Sixsmith he is quite irreverent toward him. See Salveson, 13.

41 Dalmas did produce song settings of Whitman poems, four of which were published; see notes to To the Soul: Thomas Hampson Sings the Poetry of Walt Whitman, EMI Classics compact disc 55028 (1997), which includes one of these, "As I watched the Ploughman Ploughing."

42 One is reminded by this of Allen Ginsberg's insistence that via a succession of orally transmitted accounts it is possible to trace to its source Edward Carpenter's claim to have slept with Whitman. Ginsberg traces the transmission in the 1988 television program, Voices and Visions: Walt Whitman.

43 I am dependent on Traubel's account of Brinton's letter since the original is not among his correspondence.

44 Kennedy, Reminiscenses, vii.

45 A year later Brinton resigned his membership because he was unhappy with Traubel's interpretations of Whitman and with the publishing plans of the literary executors.

46 Symonds, Walt Whitman, 79, 80.

47 Salveson claims they "had an affair" (13) but offers as evidence only a declaration of love by Sixsmith in a letter.

48 The woman was Katherine Glasier who declined his offer of a spiritual marriage to marry Bruce Glasier but remained in a quasi-romantic relationship with Wallace. See Salveson, 13. 